\title{
Teacher and student readiness using E-learning and M-learning
}

\author{
Ramadiani $^{1}$, Azainil ${ }^{2}$, Achmad Nizar Hidayanto ${ }^{3}$, Dyna Marisa Khairina ${ }^{4}$, \\ Muhammad Labib Jundillah ${ }^{5}$ \\ ${ }^{1,4,5}$ Faculty of Computer Science and Information Technology, Mulawarman University, Indonesia \\ ${ }^{2}$ Faculty of Teacher Training and Education, Mulawarman University, Indonesia \\ ${ }^{3}$ Faculty of Computer Science, Indonesia University, Indonesia
}

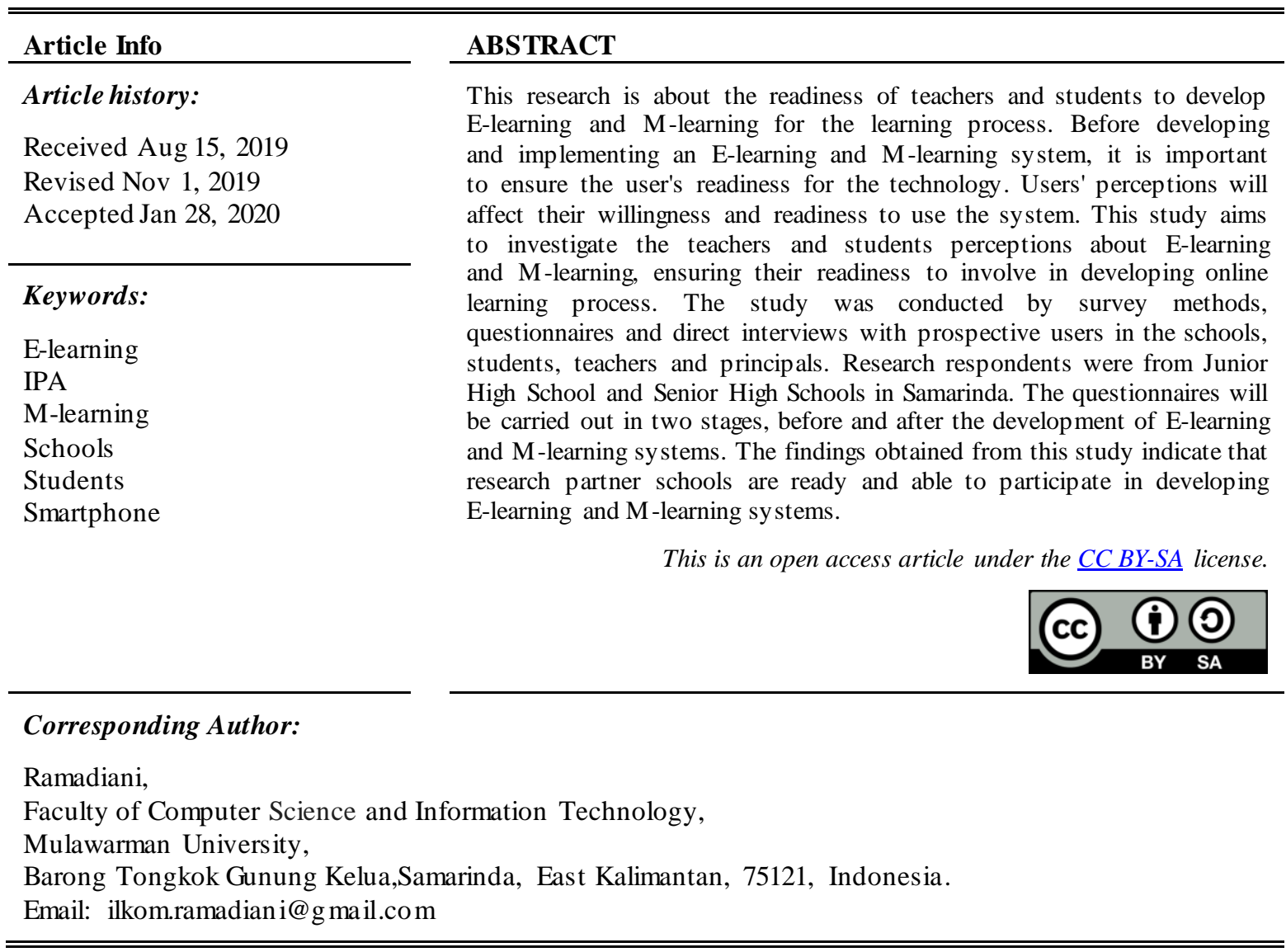

\section{INTRODUCTION}

E-learning is a system that provides various services to handle all aspects of the learning process, through an intuitive and consistent web interface. The E-learning system begins to change the orientation of learning, which previously relied on the teachers, then becomes a process of independent learning by the users, making it possible to play an active and responsible role for them. E-learning is expected to facilitate the weaknesses was found in conventional education. Through E-learning education becomes more accessible, cheaper, more enjoyable and easier to share and to learn. E-learning provides flexibility for students to be able to learn anytime and anywhere [1-5].

In the current smartphone era, information lines are wide open and easily spread so there is no more privacy in an area or country. Everyone can share information using their smartphone very quickly and easily. Events in one area can be known in other areas in seconds [1-5]. So do not be surprised if the smartphone becomes something that must be owned by everyone. If the prices of smartphones and tablets are getting cheaper, schools will be more interested in using the technology to create a learning environment for students. It is expected to positively compare to the use of E-learning and mobile learning, where students can bring their own smartphones, tablets or laptops to school [6-10]. National policy requires schools to provide wireless internet access in all classrooms so students can use their devices for learning 
activities. Open Wi-Fi networks in some schools can be a practical strategy for creating a smart school learning environment [6-10].

Some problems that still we have for developing E-learning and mobile learning are; 1) Negative views of the community and teachers about the use of mobile phones in schools. 2) Smartphones are still considered to interfere with education but their use in schools is still limited. 3) They assume that the device is nothing more than a toy that disturbs the educational value. 4) Parents and educators worry that smartphones allow inappropriate behavior such as; cheating and cyber-bullying. 5) Some schools are still reluctant to implement policies to promote M-learning [11-15].

How to develop positive M-learning content are still needs to be done and recovered. Making it easier for users to access learning material, do practice exercises and examinations, understand how to calculate mathematics quickly and other lesson formulas, whenever and wherever they need. In addition to the problems above regarding negative public views, user safety and the limitation of smartphone use in schools by policy makers. There are still more problems with other supporting facilities, electricity, internet and smartphone device. Although we believe stakeholders always enhance smartphone capabilities to become superior products. The research objectives of teacher and student readiness to develop E-learning and M-learning for this learning process are as follows:

- To measure the schools readiness using E-learning and M-learning to support their learning process.

- To build positive views and attitudes of students, teachers and the community in the face of progress in the digital era, especially schools in Samarinda.

To increase awareness and the role of teachers, students and the community related to the use of positive content on smartphones as an alternative learning.

\section{RELATED WORKS}

Internet users in Indonesia in 2018 amounted to $171,176,716.8$ with a percentage of 1 year user growth $(10.12 \%$ ), or there was a growth of internet users in 2017-2018 of 27,916,716, while the total population of Indonesia in 2018 was $264,161,600$ with a percentage of population growth of 1 year population of $(0.63 \%)$. So it can be said that the increase in internet users is higher than the growth of Indonesia's population itself. Based on the survey results, internet users in East Kalimantan amounted to $67.8 \%$ of the total population in the province, with the most age of users at the age of $15-19$ by $91 \%$, ages $20-24$ by $88.5 \%$ and ages $25-29$ by $827 \%$ [16].

Teachers make up $100 \%$ of work based internet users. Users make smartphones a source of information to support their study and work. They make smartphones as a source of information at $100 \%$, in addition to being a communication tool at $24.1 \%$, social media at $18.9 \%$, supporting work at $11.5 \%$ and learning resources $9.6 \%$ and further the reasons to find entertainment, transactions online and job demands [16].

M-learning is a part of E-learning and d-learning [10-12]. M-learning is a learning model that has characteristics, independent of location and time, is also expected to be able to provide knowledge sharing and visualization facilities so that knowledge becomes more interesting and easier to understand. The concept of M-learning is expected to encourage the realization of a new learning atmosphere and can motivate the spirit of learning and the teacher.

\subsection{The research problems}

Mobile learning is one of the potential alternatives to expand access to education. However, there is not much information regarding the use of smartphones, as learning media. This is unfortunate the level of usage is not settled for education (9.6\%). Most of the content circulating is still dominated by communication, social media, and entertainment. Many factors that become the limitations of the use of M-learning are also related to device, limited screen display, storage capacity and limited power. M-learning also has a learning environment that is different from E-learning or conventional learning. In M-learning more users utilize it in their free time, so the time to access learning is also limited [6-12].

Although it has several advantages, M-learning will not completely replace E-learning. This is because M-learning has limitations, in terms of learning media. The weakness of M-learning is gradually being overcome, with the development of advanced technology [10-15]. The Junior High School and the Senior High Schools are the few agents of change in Samarinda. The principals, students and teachers are expected as the leaders in the improving and applying the better learning process in this area. Data in this research was collected by survey and interviews about their knowledge, readiness, perception, school facilities and policy to support E-learning and M-learning. The data used open questioner and the likert scale questioners as can be seen in Table 1. 
Table 1. Data survey of schools readiness on E-learning and M-learning

\begin{tabular}{|c|c|c|}
\hline No. & & Schools readiness on implementing E-learning and M-learning \\
\hline 1 & Knowledge & $\begin{array}{l}\text { Users are familiar or not with application; contents; devices; learning method; online for um; } \\
\text { web based learning; assessment; }\end{array}$ \\
\hline 2 & Perception & $\begin{array}{l}\text { Users' opinion towards implementing online learning. easy to learn; easy to understand; easy } \\
\text { to remember; easy to use; flexible; effective; benefit; efficient; productive; according t o the } \\
\text { needs; according to ability; }\end{array}$ \\
\hline 3 & $\begin{array}{l}\text { School } \\
\text { facilities }\end{array}$ & $\begin{array}{l}\text { Availability of facilities; the appropriate mobile device and wifi/internet, rooms; electricity; } \\
\text { the processor speed; memory capacity; the output display to the tv/projector; human resource; }\end{array}$ \\
\hline 4 & Policy & $\begin{array}{l}\text { A technical support for implementing onlinE-learning; pedagogy; roles; integrated lear ning; } \\
\text { financial support; lecture attendance }\end{array}$ \\
\hline
\end{tabular}

\section{RESEARCH METHOD}

\subsection{The use of M-learning}

Many factors influence a person to choose and use an application that is planted on a smartphone including M-learning. Variables that will be hypothesized in this study are used to build models of M-learning user acceptance. Variables that are important to observe are user knowledge, user perception, schools facilities, policy and readiness [1-6, 15-20]. The respondents in this study came from 3 schools; namely SMPN1, SMAN2 and SMAN3 Samarinda, which consists of three school principals, five deputy principals, seven teachers and sixty students.

\subsection{Importance performance analysis (IPA)}

User satisfaction is the user's perception; this is related to user expectations, product quality, and services from the organization. The IPA method can measure the level of user satisfaction from the results of the user questionnaire based on components of service and product attributes, namely: The Importance of the services and products to users and the level of organizational performance in providing these services and products.

The IPA technique combines measures of performance and perceived interests of users into a two-dimensional plot to facilitate interpretation of data [21-26]. This plot groups attributes into four quadrants to specify in allocating limited resources. Four quadrants are usually identified as the main priority (quadrant I), maintain performance (quadrant II), low priority (quadrant III), and excessive (quadrant IV).

\section{RESULT AND DISCUSSION}

\subsection{Survey results}

In the Figure 1, there is a strong correlation (0.709). Between E-learning and quality of learning, this shows that the stronger the understanding of E-learning, the stronger the quality of the institution. There is a correlation/positive relationship (of 0.361) between E-learning and the use of smartphones, this shows that the more smartphone users the better the E-learning understanding. There is no relationship between E-learning and smartphone usage behavior. There is a correlation of 0.284 between the uses of smartphones with the quality of learning; this shows that the more smartphone usage, the better the quality of learning will increase. There is no relationship between the behaviors of smartphone users with the quality of learning. There is a relationship of 0.487 between smartphone users and smartphone user behavior. As many as $35 \%$ of the teacher use the internet to access information, $23 \%$ for learning process, $15 \%$ to increase human resource and $12 \%$ for the technological progress as shown in Table 2.

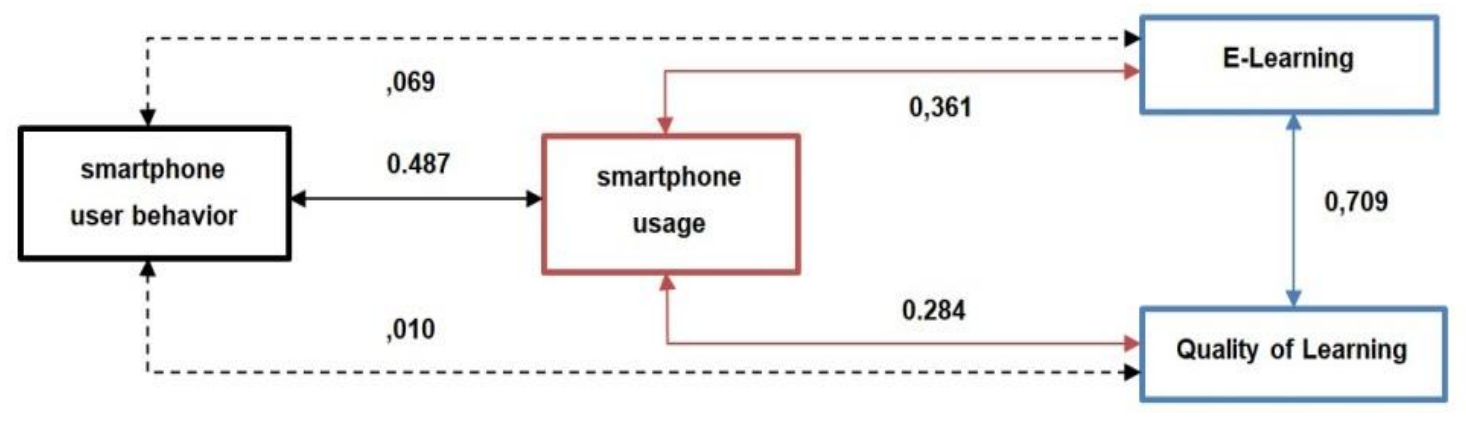

Figure 1. The correlation between smartphone usages to E-learning 
In the next table describe the school policy on how to divide the internet into spaces, and use it to support their E-learning process. The policy was prepared by the school principals and teachers according to the constitution, the student parents, and local government's roles as shown in Table 3. E-learning website that is always used by the respondents is YouTube (19\%), ruangguru.com (12\%), edmodo (11\%), rumah belajar (9\%), quiziz (8\%), schoology (14.29), and one stop E-learning and zenius.net in $6 \%$. The quipper and the ministry of education and culture learning website are $5 \%$ as we can see in Table 4. In Table 5, most respondents use E-learning (26\%) to enhance their abilities and knowledge, and to provide online assignments and exams, (18\%) facilitate access to assessment and (13\%) to support their learning material.

Table 2. Teacher's reasons use the internet

\begin{tabular}{|c|c|c|c|}
\hline No & Reason & Amount & Percentage $(\%)$ \\
\hline 1 & $\begin{array}{l}\text { Accessing } \\
\text { Information }\end{array}$ & 9 & 35 \\
\hline 2 & Learning process & 6 & 23 \\
\hline 3 & Increased HR & 4 & 15 \\
\hline 4 & $\begin{array}{l}\text { Technological } \\
\text { Progress }\end{array}$ & 3 & 12 \\
\hline 5 & $\begin{array}{l}\text { For UTBK, UNBK, } \\
\text { PPDB, etc }\end{array}$ & 2 & 8 \\
\hline 6 & $\begin{array}{l}\text { Use the school } \\
\text { database }\end{array}$ & 2 & 8 \\
\hline
\end{tabular}

Table 4. Learning websites which the respondents always used

\begin{tabular}{llcc}
\hline Vo & \multicolumn{1}{c}{ E-learning } & Amount & Percentage $(\%$ \\
\hline 1 & YouTube & 45 & 19 \\
2 & Ruangguru.com & 29 & 12 \\
3 & edmodo & 25 & 11 \\
4 & rumah belajar & 22 & 9 \\
5 & Quiziz & 19 & 8 \\
6 & schoology & 16 & 7 \\
7 & one stop E-learning & 15 & 6 \\
8 & ZENIUS.NET, Quipper & 25 & 11 \\
9 & learn Kemendikbud & 11 & 5 \\
10 & geogebra & 9 & 4 \\
11 & dapodik & 8 & 3 \\
12 & Kahoot, sigil & 11 & 5 \\
\hline & & 235 & 100.00 \\
\hline
\end{tabular}

Table 3. The school policy to support online learning

\begin{tabular}{clcc}
\hline No & \multicolumn{1}{c}{ Reason } & Amount & Percentage (\%) \\
\hline 1 & $\begin{array}{l}\text { Dividing the internet } \\
\text { into rooms }\end{array}$ & 8 & 30 \\
2 & $\begin{array}{l}\text { Given a different } \\
\text { password every room }\end{array}$ & 4 & 15 \\
3 & $\begin{array}{l}\text { Internet usage settings } \\
\text { for each st udents }\end{array}$ & 3 & 10 \\
4 & $\begin{array}{l}\text { Part of it is used in the } \\
\text { digital library }\end{array}$ & 4 & 15 \\
5 & Used when learning & 8 & 30 \\
\hline & & 27 & 100.00 \\
\hline
\end{tabular}

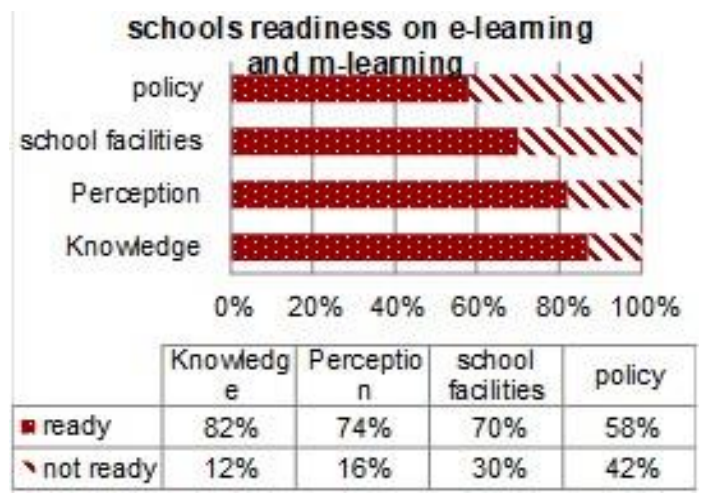

Table 5. The purpose of using E-learning websites

\begin{tabular}{clcc}
\hline No & $\begin{array}{l}\text { The purpose of using E-learning } \\
\text { websites }\end{array}$ & $\begin{array}{c}\text { Amou } \\
\mathrm{nt}\end{array}$ & $\begin{array}{c}\text { Percentage } \\
(\%)\end{array}$ \\
\hline 1 & $\begin{array}{l}\text { Enhancing abilities and } \\
\text { knowledge }\end{array}$ & 60 & 26 \\
2 & $\begin{array}{l}\text { provides online assignments and } \\
\text { exams }\end{array}$ & 60 & 26 \\
3 & facilitates access to assessments & 43 & 18 \\
4 & accessing learning material and & 30 & 13 \\
5 & media & 22 & 9 \\
6 & many features for learning & 18 & 8 \\
\hline & help students in learning & 233 & 100 \\
\hline
\end{tabular}

Figure 2. The user readiness and user expectation on E-learning and M-learning

Schools readiness on E-learning and M-learning in Figure 2 was collected from seventy-five respondents consist of twenty-five head master and teachers and also sixty students. The question is about their knowledge, their perception, school facilities and policy. Their knowledge are familiar or not with the application. Their perception is about implementing online learning, availability of facilities and the policies or technical support for implementing online learning as shown in Table 1. Figure 3 describes the chart of distribution IPA quadrants based on the coordinate points. 


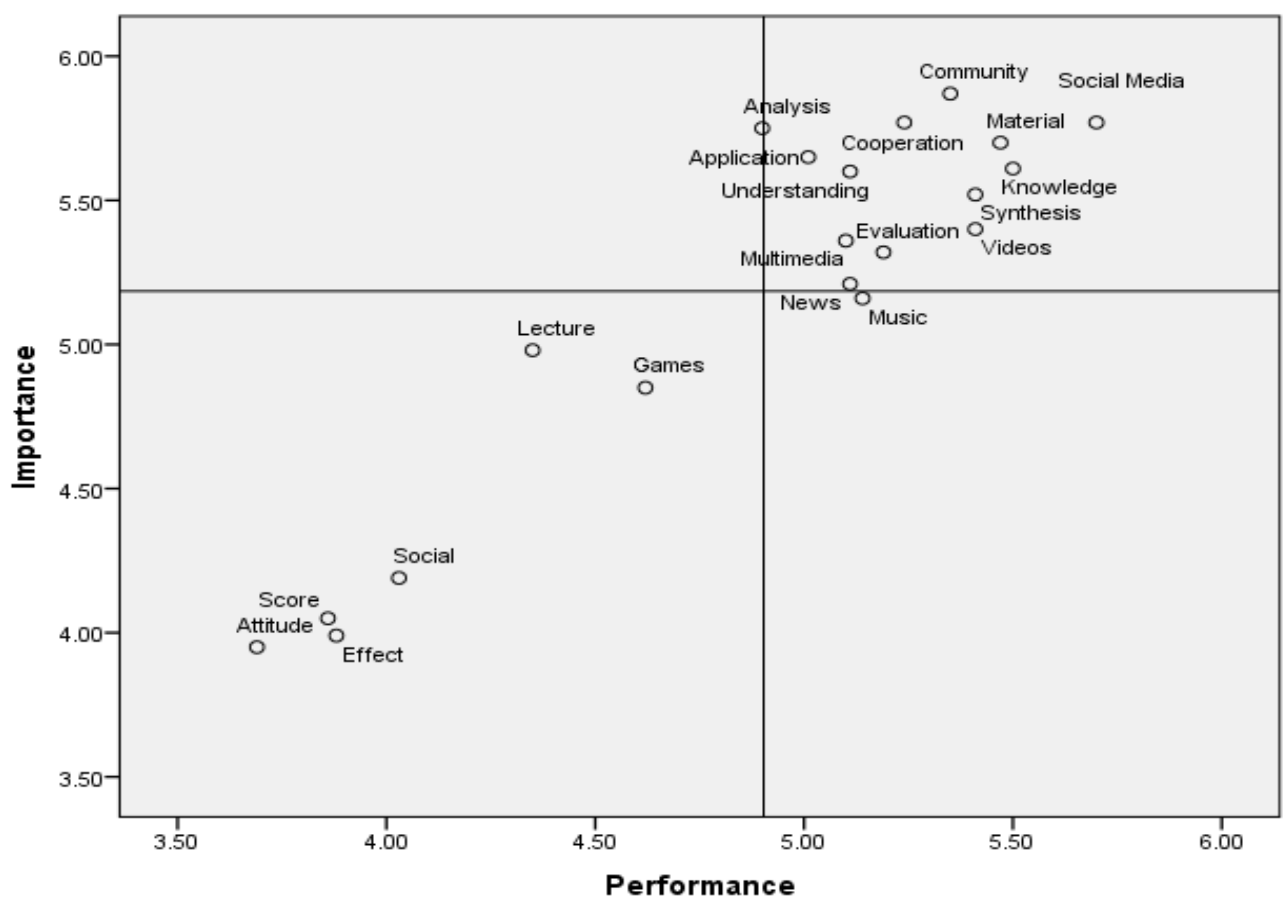

Figure 3. Distribution of IPA quadrants

Based on the results of the four quadrant IPA graphs in the Figure 3 and Table 6, it can be concluded the criteria that fall into each quadrant are: quadrant I has a relatively high level of importance but has lacking performance so it needs to be improved in E-learning performance. The category included in this quadrant is analysis. Quadrant II has a relatively high level of importance with a relatively high level of performance so that it is in accordance with the expectation of the user and must be maintained. The categories included in this quadrant are community, collaboration, materials, social media, knowledge, synthesis, application, understanding, multimedia, evaluation, video, and news. Quadrant III has a relatively low level of importance with a relatively low level of performance so that it does not need to make improvements because it is not a top priority of the user. Categories included in this quadrant are lecture, games, social, values, effects, and attitudes. Quadrant IV has a relatively low level of importance but has a relatively high level of performance so the school needs to relocate these excess performance resources to other quadrants that need performance improvement. The category in this quadrant is music.

Table 6. IPA coordinates

\begin{tabular}{clccc}
\hline No & Category & Importance & Performance & Quadrant \\
\hline 1 & Material & 5.70 & 5.47 & Quadrant II \\
2 & Community & 5.87 & 5.35 & Quadrant II \\
3 & Lecture & 4.98 & 4.35 & Quadrant III \\
4 & Cooperation & 5.77 & 5.24 & Quadrant II \\
5 & Multimedia & 5.36 & 5.10 & Quadrant II \\
6 & Knowledge & 5.61 & 5.50 & Quadrant II \\
7 & Understanding & 5.60 & 5.11 & Quadrant II \\
8 & Application & 5.65 & 5.01 & Quadrant II \\
9 & Analysis & 5.75 & 4.90 & Quadrant I \\
10 & Synthesis & 5.52 & 5.41 & Quadrant II \\
11 & Evaluation & 5.32 & 5.19 & Quadrant II \\
12 & Videos & 5.40 & 5.41 & Quadrant II \\
13 & Social Media & 5.77 & 5.70 & Quadrant II \\
14 & Music & 5.16 & 5.14 & Quadrant IV \\
15 & Games & 4.85 & 4.62 & Quadrant III \\
16 & News & 5.21 & 5.11 & Quadrant II \\
17 & Attitude & 3.95 & 3.69 & Quadrant III \\
18 & Social & 4.19 & 4.03 & Quadrant III \\
19 & Score & 4.05 & 3.86 & Quadrant III \\
20 & Effect & 3.99 & 3.88 & Quadrant III \\
\hline
\end{tabular}




\section{CONCLUSION}

According to this research, it can be concluded that analysis has a relatively importance in E-learning and M-learning, but it needs to be improved in E-learning performance. Community, cooperation, materials, social media, knowledge, synthesis, application, understanding, multimedia, evaluation, video, and news should be has in E-learning and M-learning. They are very importance and high performance accordance to their user expectation and must be maintained (in quadrant II). Game, attitude, social, value, effect and music is not important but music has high performance. The suggestions to the next research to involve more respondents from various schools, institutions, and places in Indonesia to measure their readiness on implementing E-learning and M-learning.

\section{ACKNOWLEDGEMENTS}

This research was funded by the Directorate of Research and Community Service, the Directorate General of Research and Development of the Ministry of Research, Technology and Higher Education of the Republic of Indonesia.

\section{REFERENCES}

[1] Ramadiani et al., "User satisfaction model for E-learning using smartphone," Proc. Comp.Sc., vol. 116, pp. 373-380, 2017.

[2] Ramadiani et al., "Integrated model for E-learning acceptance," IOP Conf. Series: Materials Science and Engineering, vol. 105, pp. 1-9, 2016.

[3] Ramadiani et al., "E-learning user acceptance based on analysis of user's sty le, usability, and user benefits," Jurnal Aiatem Informasi, vol. 9, no. 1, pp. 6-12, 2013.

[4] Ramadiani et al., "Model dan bentuk penelitian E-learning menggunakan structural equation model," Mulawarman University Press. 2018.

[5] R. Ramadiani, A. Azainil. F. Frisca. A. N. Hidavanto. H. Herkules.” An integrated model of E-learning continuance intention in Indonesia," International Journal of Innovation and Learning, vol. 26, no. 1, pp. 1-26, 2019.

[6] R. Christensen and G. Knezek, "Readiness for integrating mobile learning in the class room: Challenges, preferences and possibilities," Computers in Human Behavior, vol. 76, pp. 112-121, 2017.

[7] A. Abu-Al-Aish, S. Love, and Z. Hunaiti, "Mathematics students' readiness for mobile learning," International Journal of Mobile and Blended Learning, vol. 4, no. 4, pp. 1-20, 2012.

[8] Ramadiani, R. Atan, M. H. Selamat, R. Abdullah, N. C. Pa and Azainil. "User difficulties in E-learning sy stem," 2nd International Conference on Science in Information Technology (ICSITech), pp. 158-162, 2017.

[9] O. Ozan, G. T. Yamamoto, and U. Demiray. "Mobile learning technologies and educational applications," FORMAMENTE- Anno X, vol. 3, no. 4, pp.97-109, 2015.

[10] UNESCO Working Paper Series on Mobile Learning, "Turning on mobile learning in Europe: illustrative initiatives and policy implications," United Nations Educational, Scientific and Cultural Organization, 2012.

[11] I. Rakhmani and S. A. Pangerapan, "Profil pengguna internet di indonesia 2014," APJII and PusKaKom UI, 2015.

[12] M. Akintolu, O. Adelore, and D. R Nzima, "Attitude of learners toward the use of mobile technology for adult literacy programme," J. of Gender, Information and Development in Africa (JGIDA), vol. 8, no. 1, pp. 63-82, 2019.

[13] I. K. Yusri, R. Goodwin, and C. Mooney. "Teachers and mobile learning perception: Towards a conceptual model of mobile learning for training," Procedia - Social and Behavioral Sciences, vol. 176, pp. 425-430, 2015.

[14] M. Sharples, "Disruptive devices: Mobile technology for conversational learning," International Journal of Continuing Education and Life-long Learning, vol. 12, no. 5-6, pp. 504-520, 2002.

[15] M. Sharples, "Mobile learning: research, practice and challenges," Dist. Edu. in China, vol. 3, no. 5, pp. 5-11,2013.

[16] Tim APJII, "Survei nasional penetrasi pengguna internet 2018," Buletin APJII. Polling Indonesia. pv. 1-51.2018.

[17] E. S. Georgievaa, A. S. Smrikarova, and T. S. Georgieva, "Evaluation of mobile learning system," Procedia Computer Science, vol. 3, pp. 632-637, 2011.

[18] H. Bicena and S. Kocakoyun, "The evaluation of the most used mobile devices applications by students," Procedia - Social and Behavioral Sciences, vol. 89, pp. 756-760, 2013.

[19] A. Mohamed, "Mobile learning: Transforming the delivery of education and training," Edmonton: AU Press Issues in Distance Education series, Athabasca University, 2009.

[20] Y. Padmanathan, and L. N. Jogulu. "Mobile learning readiness among Malaysian polytechnic students," Journal of Information System and Technology Management, vol. 3, no. 8, pp. 113-125, 2018.

[21] A. Z. Shaqour, "Students' readiness towards m-learning: A case study of pre-service teachers in Palestine," Journal of Educational and Social Research. vol. 4. no. 6. pp. 19-26. 2014.

[22] H-H. Lin, S. Lin, C-H. Yeh, and Y-S. Wang, "Measuring mobile learning readiness: scale development and validation," Internet Research, vol. 26, no. 1, pp. 265-287, 2016.

[23] J. A. Martilla and J. C. James, "Importance-performance analy sis," J. of Marketing, vol. 41, no. 1, pp. 77-79, 1977.

[24] M. S. Wong, H. Nishimoto, and G. Philip, "The use of importance performance analysis (IPA) in evaluating Japan's e-government services," J. of Theo. and Appl. Elec. Commerce Research, vol. 6, no. 2, pp. 17-30, 2011.

[25] S. Fatima and P. O. Fernandes, "Empirical study on the student satisfaction in higher education: Importancesatisfaction analysis," World Academy of Science, Engineering and Technology, vol. 6, pp. 1075-1080, 2012. 
[26] C. H. Wu, Y-C. Lee, Y-C. Cheng, and S-B. Tasi, "The use of importance performance analy sis (IPA) in evaluating bank services," Int. conf. on serv. Syst. and service management (ICSSSM), vol. 11, pp. 654-657, 2012.

\section{BIOGRAPHIES OF AUTHORS}

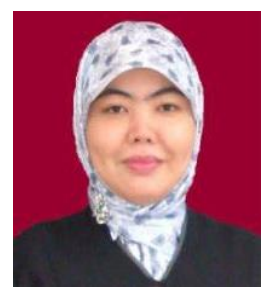

Ramadiani obtained her Ph.D in Information System from Univesiti Putra Malaysia (UPM) in 2015. She received her first degree from Mulawarman University (1996), her M.Kom. in Computer Science from Gadjah Mada University (2006). Ramadiani currently works at the Department of Computer Science, Mulawarman University. Ramadiani does research in Software Engineering, Information Systems and Human-computer Interaction. Her current project is 'e-Learning' and Decision Support System.

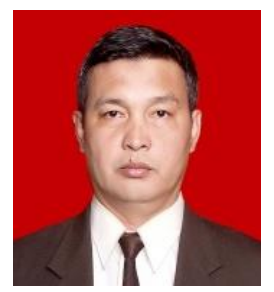

Azainil received his first degree from Sriwijaya University (1990), his M.Si from Bogor Agricultural University (2003). He completed his Dr. in Education Management degree from Jakarta State University in 2012. Currently, he is a senior lecturer at Faculty of Teacher Training and Education, Mulawarman University. His research mainly focuses on Education Management, Management information System, Education Quality Management, Information and Communication Technology, Mathematics Education.

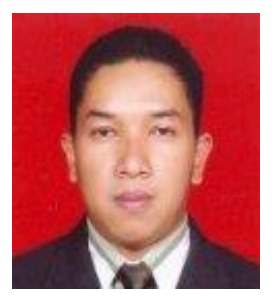

Achmad Nizar Hidayanto obtained his Dr. in Computer Science from Indonesia Univesity in 2008. He received her first degree and Magister in Computer Science also from Indonesia University in 1999 and 2002. Achmad Nizar Hiday anto currently works as head of Information Systems Program, Indonesia Univesity. He does research in Information Systems, IT Adoption, Digital Economic, and Financial technology.

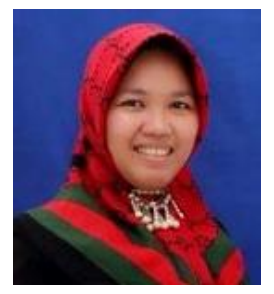

Dyna Marisa Khairina S.Kom, M.Kom. She graduated her master degree in Information System (2012) from Diponegoro University Semarang Indonesia. He obtained his S.Kom from Mulawarman University (2007) Samarinda. His research interests area in Information System, Decision Support Sy stem, Enterprise Resource Planning and Management information System.

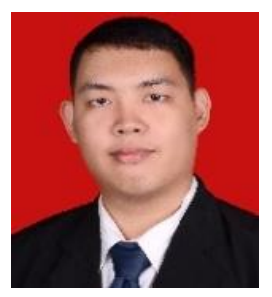

Muhammad Labib Jundillah S.Kom, M.Kom received his M.Kom degree in Information System (2019) from Diponegoro University Semarang Indonesia. He obtained his S.Kom from Mulawarman University (2017) Samarinda. His research interests area in Information System, Decision Support System, E-learning, and User Statisfication. 